\title{
The Customary Law Nature of Sustainable Forest Management States Practice in Central America and European Union
}

\author{
Samuel Assembe-Mvondo \\ CIFOR Central Africa Regional Office, Forests \& Governance Program; Researcher Officer; and PhD candidate \\ University of Eastern- Finland; P.O. Box: 2008, Yaounde-Cameroon \\ E-mail: s.assembe@cgiar.org
}

\begin{abstract}
Sustainable forest management (SFM) has become one of major environmental debates for the international community. This is because of the multifunctional importance of forest resources for the entire planet, namely ecological, socio-economic, cultural and climatic balance. General awareness of the multifunctional importance of forests unfortunately coincides with the observed increase of threats to these 'international public goods'. To tackle continuous deforestation and degradation, the international community through the UNFF and its predecessors has attempted to adopt an international legally-binding agreement on sustainable management based on the Forest Principles. The narrow success of such international negotiations led to explore another option to this issue through the review of some regional agreements based on the inductive approach. This method is used by International Court of Justice for seeking the customary international law through the States behaviours or conducts. The paper is focussed on two regional regimes on SFM: the Central America Regional Convention and the European Union Resolution related sustainable forests management. The examination of States practice shows that such regional instruments fulfil all the requirements for having the status of the emerging customary law at these regions.
\end{abstract}

Keywords: Sustainable forests management (SFM), Customary international law, States practice, Central America, European Union, Legally- binding

\section{Introduction}

Forests play a key role in the development and lives of communities worldwide. In fact, they are carbon dioxide traps and biodiversity reserves (Humphreys and Palo, 1998; Schoene and Netto, 2005). This ecological function of forests contributes to the natural balance the planet needs (CARPE, 2005). Hence, they play a major role in the water cycle by preventing loss, providing ground water and purifying water. Also, forest resources have an economic function; they provide timber, raw materials for pharmaceutical industries that use vegetable fiber and Non-Timber Forest Products. Agro-forests provide raw materials such as rubber, arabic gum, spices etc. International trade in forest products is fast growing. International trade in timber byproducts was estimated at 140 billion K in 2003 (Hashiramoto et al., 2004).Consequently, forest resources are important to the global economy. Furthermore, forests have a socio- cultural function for millions of people. They serve as a place of distraction for urban people stressed by the negative effects of modernity (FAO, 2005). Also, it is a natural stock for food, pharmacopeia and beliefs of local people who live in these natural ecosystems, especially in tropical regions (Ndoye \& Chupezi, 2004). Because of these three functions, the UN Millennium Development Goals (MDG) made forest resources one of the tools in the fight against poverty and threats to the environment (Vähänen, 2006). However, interactions between these three principal functions are too complex, because they are difficult to reconcile. Most often their interests are rather conflicting, as each stakeholders desires to valorize certain functions that are of importance to them.

Despite international community awareness of the importance of natural resources, problems inherent in forests are numerous and persistent, even regarding the definition of the term. At international level, there are several definitions on what constitutes a forest (FAO, 1999). Obviously, forests ecosystems vary according to the distinctions between types of forests: tropical forest; temperate forests; boreal forests. Each one of these forest ecosystems includes several subtypes, which have special characteristics in terms of vegetation and fauna (Burley, 2002). This distinctive classification of forest blocks is at the heart of current discussions on sustainable management. Consequently, it is difficult, logically, to have uniformity in perceptions and practices, with regards to specificities inherent in the heterogeneous natural factor of forests.

For over thirty years, international law has been a tool for the protection of the environment and natural resources (Sands, 1995). Kuokkanen (2002), shows that the relationship between international law and the environment can be subdivided from the historical and substantive point of view into three successive periods: traditional, modern and postmodern. Each period has particular characteristics. This constant solicitation of international law in environmental management resulted in a kind of normative increase in the establishment of regulations for the global environment and for the preservation of natural resources (Daillier and Pellet, 2002). This recourse to international law is largely justified by the extent of the problems the worlds' environment faces. In its Advisory Opinion on the environment and as a guide for countries and other actors, the dictum of the International Court of Justice (ICJ, 1996), was: “...that the environment is not an abstraction but represents the living space, the quality of life and the very health of human beings, including generations unborn". 
This analysis is made in a global context marked by the effect of various paradigms of different types, which influence forest management and international law at the same time (Dryzek, 2007). Indeed, according to Dryzek (2007), paradigms in the management of the global environment are products of natural science and social sciences as well. First of all, forests are threatened by the increase of deforestation. According to FAO estimates that 13 million hectares of forests are affected by deforestation each year (FAO, 2007). Thus, in 15 years (1990-2005), the world has lost 3 percent of its total forest cover, which represents an average loss of 0.2 percent per year. This decrease of forest cover affects the volume of carbon stored in forest biomass. In fact, a decrease of almost 5.5 percent of the world's biomass was noted between 1990 and 2005(FAO, 2007). This decrease also affects wildlife resources. The causes of the destruction of forest resources are numerous and well known (CBFP, 2006): population growth; uncertainty over ownership rights; poaching and meat bush trade; slash and burn agriculture; non-sustainable industrial logging; illegal logging; mining; climate change; construction of roads; fires; invasive plants; wars; poor governance and corruption. Secondly, the context is marked by the negative effects of climate change on the planet (Stern, 2006; IPCC, 2007). In fact, the destruction of forest resources will logically increase, especially because of disturbing and worsening phenomena like fires, plant diseases and pests. This sinister scenario is aggravated by the interconnection of between the climate, ecology, forests and biodiversity. Taking in consideration of the later evolutions/trends, our concern in this paper is mainly to analysis the construction process of an international forest law by reviewing subregional dynamics.

The literature shows that previous studies on the existence of an international forest management regime all came to the conclusion that there exists a body of rules. These rules are fragmented, incomplete and dispersed in various international conventions (Tarasofsky, 1999; Ruis, 2001; Smouts, 2008). However, an approach for the codification of these rules has been explored (Brunnée, 1996). With regards to international law, the general concept of sustainable development was first of all a declaration in the beginning, thus voluntary for all stakeholders. Second, Governments were called upon to disseminate and translate them into concrete actions. Third, the decision by the International Court of Justice (ICJ), in the Case concerning Gabcikovo - Nagymaros (ICJ, 1997), the international court highlighted the need to consider new requirements based on the concept of sustainable development when States envisage new initiatives, or when they carry on with past activities. Additionally, the Permanent Court of Arbitration (PCA, 2005), arrived at almost similar conclusions in the arbitration regarding the Iron Rhine Railway, between the Kingdom of Belgium and the Kingdom of the Netherlands. Lastly, some scholars have just asserted that the concept of sustainable development is now part of international law (Cordonier Segger, 2008; Schrijver, 2008).

Consequently, given these recent theoretical and jurisprudential developments mentioned above, it is convenient to analyze the relationship between principles of sustainable forest management and customary international law through States practice in Central America and European Union. The premise of this paper is that States practice related SFM should be considered as part of regional customary law. In this way, this article seeks to find customary law through the review of States practices on sustainable forests management in both Central America and European Union States. The first part of the paper is devoted to conceptual clarifications. The second section focuses on the study of sustainable forest management in both regions. The third section discusses the sustainable forest management States practice according the requirement of customary international/regional law.

\section{Conceptual framework of the review}

\subsection{Concept of SFM and synthesized definitions}

It is generally recognized that the concept of SFM falls within the matrix of sustainable development. This expression was used in the Brundtland Report (1987), titled "Our Common Future" submitted to the UN World Commission on Environment and Development. It suggests that future activities by the international community should focus on: "development that seeks to meet the needs and aspirations of the present without compromising the ability to meet those of the future". Consequently, States present at the 1992 United Nations conference on Environment and Development, held in Rio in, unanimously adopted the Declaration and committed to "cooperate in good faith and in a spirit of partnership in the fulfilment of the principles embodied in this Declaration and in the further development of international law in the field of sustainable development". One of the main attractions of this world forum was undeniably the issue of the management of the world's forests, given that it resulted in a Declaration of a 'Non-legally Binding Authoritative Statement of Principles'. Article 2 (b), of the Declaration states that, "Forest resources and forest lands should be sustainably managed to meet the social, economic, ecological, cultural and spiritual needs of present and future generations". Consequently, the sustainable management of forest resources is an issue of concern for the international community, States and multilateral organizations.

However, from a historical point of view, some sources date SFM practices before Rio 1992 (FAO, 2005). Indeed, it seems many countries already practiced good forest management, considering social, cultural, economic, ecological and future aspects, which are the main concern of the current concept. Hence, the similar concept of 'sustainable and balanced production' was applied for close a little over a decade, in the management of watersheds and other measures of conservation of forest lands and water (Maini, 1992). This idea of the existence of the concept before the Rio Summit is confirmed in 1983 International Tropical Timber Agreement. Though the 
wording in this agreement is not precise, the idea of sustainability is knitted into the expressions 'maintaining the ecological balance of the regions concerned' and 'sustained utilization and conservation of tropical forests'. To confirm this pioneering initiative aimed at forest sustainability, ITTO, the administrative organization of this international agreement, launched a study to assess the state of the sustainable management of tropical forests in its Member States. The title of the study (Poore et al., 1989), says it all - "No Timber without Trees: Sustainability in the Tropical Forest". At any rate, intentions to orientate forest management practices towards sustainability and conservation had come up before Rio. However, the concept was standardized and became clear after 1992.

The concept of SFM is of major importance in the literature. This is revealed by the plethora of studies and articles on the subject. Nevertheless, there are many definitions of the SFM. To date, there is a universally accepted definition of SFM that is not subject to criticism (Vogt et al. 2000). In this analysis, we will look at some of these definitions, drawn from documents, as well as from institutional frameworks. Ambiguities in the definition of the expression 'sustainable management of forests' came up relatively after Rio, during the 1993 Conference of European Ministers in charge of Forests, held in Helsinki. Within this formal framework, sustainable forest management was defined (MCPFE, 1993):

"Stewardship and use of forest and forest lands in such a way, and at a rate, that maintains their productivity, regeneration capacity, vitality and their potential to fulfil now and in the future, relevant ecological, economic, and social functions, at local, national, and global levels, and that does not cause damage to other ecosystems".

The definition of sustainable forest management by Bruenig (1996), states:

"The management of a forest as a diverse and dynamic self- sustainable renewable natural resource in such a manner that its continued and lasting (permanent) persistence, viability, vitality, flexibility, resilience and adaptability, as well as its natural-ecological, environmental, economic and social values and multiple social utilities are ensured and, if possible, enhanced for the benefit of the present and future generations of humankinds". Finally, according to Maini (1992), SFM entails continuous maintenance, without unacceptable deterioration of the resilience and production capacity, as well as the ecological and varietal diversity of forest ecosystems. Thus, forest sustainability entails integrated forest management, maintenance of the ecological integrity of the forest environment and the preservation of future options.

It seems like all the forest sustainability definitions have a common ground. This synthesis of the definitions of forest sustainability draws on the work by Swerdrup and Mats Swensson (2002). Their premise is based on the principle of human goodwill. According to these researchers, the elements and criteria for forest sustainability must be simple and basic so that the common man can make a free judgment on the said subject. To this end, the definition of the terms must be practical and functional. Equally, the rules of SFM should be clear and comprehensible to all stakeholders.

Thus, based on the reasoning of Swerdrup and Mats Swensson (2002), one can see some constancies and similarities in the different conceptual definitions. First, the concept entails 'ecological sustainability'. This sustainability refers to the long-term use of forest resources. This implies preserving the productivity of forest biomass, preserving the auto-reproduction potential of biodiversity, maintaining the physical stability of forest lands; maintaining nutrients and maintaining the chemical condition. Secondly, these definitions mention the 'social sustainability' function. From this angle, it defines the stability of social organizations and its components, the resilience of the system as a basic requirement in the face unstable individual or collective rights. This second definition implies that access to forests should be a civil right. The forest provides multiple services to communities, thus the public can request the maintenance of the forest at standards it considers acceptable, as forests should generate opportunities for communities. Thirdly, there is also the aspect of 'economic sustainability' From this point of view, it entails exploiting forest resources in a balanced manner, and striking a balance between economic principles and other natural and social principles.

A look at the different definitions shows another very important factor, which makes of sustainable management a goal. Sustainability is thus never achieved or static. It is a permanent and constant aim, because finding the right balance between ecological, social and economic needs, is a very long term activity. Discussions on forest sustainability tend to evade this aspect of the concept as an objective, which should be central to all activities toward the management of this environmental resource. In other words, with regard to sustainable management of forests it is more realistic to aim at a means that would lead to a perfect state of sustainability (Bruenig, 1996). In fact, implementing principles of sustainable forest management in all forest blocks in the world is an endless process. Thus, the sustainable management of forests is a "constant adjustment to the ecological, economic, social, intellectual and natural changes of the environment". Their orientation is long term, even very long term, that is, over many generations (Princen, 2003). Finally, forest sustainability is quite simply an aim that can be achieved through principles, tools and practices on the ground.

\subsection{Customary international law (CIL)}

International law is not meant to only address a specific type of problem; it may also recourse to international custom (Condorelli, 1991)]. According to provisions of article 38 (1. b) of the Statutes of the International Court of Justice (ICJ): "The Court, whose function is to decide in accordance with international law such disputes as are 
submitted to it, shall apply: International custom, as evidence of general practice accepted as law." In fact, this is actually one of the principal formal sources of the rules of international law.

Generally, there are two opposing theoretical and traditional schools of thought on the issue namely, positivists and jusnaturalists (Akehurst, 1975). Simply put, positivists hold that the source of normativity is inherent in the behavior of States, subjects of primary law. A contrario, according to jusnaturalists, it is the community of States and basic rules of behaviors that cross it and make it obtain, which is the basis of international law (Kennedy, 1987). This traditional opposition between these two schools of international law crossed over to the basis of customary international law through two theories: the theory of "the tacit agreement" or the subjective conception of custom and the theory of "spontaneous formation" or the objective conception of custom. According to Thirlway (2003): "custom which pre-supposes an established practice and psychological element known as the opinio juris is in principle binding on all states". Consequently, the traditional customary process is important, as it bases on the distinction between the two main foundations of customary international law (Ferrari-Bravo, 1986): the material element or States' practice, referred to in Latin as Consuetudo; the psychological element or Opinio juris sive necessitatis.

\subsubsection{Material element: Consuetudo}

The formation of international custom is based on the practice of subjects of international law (Thirlway, 2003). By practice of subjects of international law we mean any behavior of States or multilateral organizations that reveals the knowledge of such subject of an international legal situation (Boisson de Charzournes, 2004). In other words, practice in international law is the behavior/act of the subjects (Henckaerst, 2005). The behavior or act of States and multilateral organizations may be in accordance with domestic or international legal texts, yet this is not enough. The act should come from subjects of international law on the one hand. On the other hand, the positive or negative behavior of a State should reveal its acts or actions on the international scene. The conduct of States may be material and verbal (ILA, 2000).

The acts of States may (Boczeck, 2005), first of all be carried out by diplomatic bodies through correspondences to other States or international organizations; diplomatic notes, verbal notes, memos, diplomatic letters, documents on general declarations of the policy of a country, the opinion of an agent representing a State etc. Also, acts may be the practice of parliamentary institutions: parliamentary discussions, voted laws, general discussions. Moreover, it may be an act by domestic jurisdictions. Lastly, the phenomenology of States practice can also come from acts by international organizations: decisions by international courts and tribunals, treaties and international conventions, Statement principles, summit declarations, resolutions, and official reports. There are three categories of acts by international organizations. Some are declarations of preexisting customs, others consolidate a custom in formation and the third category generates new customs. However, there are two conditions connected to the recognition of the conduct/act of states as practice: repetition of acts over time and in space.

Firstly, the repetition is a condition that consolidates a practice, without which there would be no custom; 'a practice must be repetitio facti'. The need for repetition is demonstrated by the recourse to expressions borrowed from international jurisprudence, such as "constant international practice"; or a "constant and uniform practice" (ICJ, 1986). Repetition over time can be verified at two levels: i) uniformity of the practice of States, which means the successive acts of a State, should be similar. They must be similar in theory to each other. In the absence of this constant uniformity, there would be no repetition. However, uniformity does not exclude the possibility of violation (PCIJ, 1927); ii) the duration of the practice; in the traditional view, a practice should have occurred tens of years before hand or be in use for a very long time (ICJ, 1969). However, in recent years there has been an intensification of interstate relations. In fact, passage of time (duration) has lost its importance; international court considers intensity more important in a practice. Hence, in the North Sea Continental Shelf Case (ICJ, 1969), the court affirmed that a State practice could be considered a custom only after passage of time without any precision.

Secondly, the repetition of a practice should not be done by only the State or a particular international organization that implements such act. In fact, it is important to differentiate between universal custom and regional custom: i) Universal customary rules, according to provisions of article 38 (b) of the ICJ statutes, result from general but non-unanimous practice, because the latter aspect is not easily attainable. International jurisprudence confirmed this in the North Sea Continental Shelf Case declaring that (ICJ, 1969): “... a very widespread and representative participation might show that a conventional rule (has become) a general rule of international law, given that it includes States concerned". The representative participation: the Court refers to entails the involvement of the "States particularly interested" in the growing custom; ii) international law also recognizes the existence of regional customary law/rules. Moreover, in the Asylum Case (ICJ, 1950), the Court confirmed this by deciding that diplomatic asylum was not a regional custom in South America.

\subsubsection{Psychological element: Opinio juris sive necessitatis}

A practice means nothing if it is not accompanied by the belief that it corresponds to a legal obligation: opinio juris. Hence, it is generally recognised that a simple repetition of an act is not enough, and that a customary rule can only exist if the act in question is motivated by the awareness of a legal obligation. In this light, international law issues tend to be legally related. In practice, this theoretical requirement to be bound by opinio juris has been validated by 
international courts. Consequently, in the North Sea Continental Shelf Case (ICJ, 1969), the court affirmed this requirement in the following terms:

"Not only must the acts concerned amount to a settled practice, but they must also be such, or be carried out in such away, as to be evidence of a belief that this practice is rendered obligatory by the existence of a rule of law requiring it. The need for such a belief, i.e., the existence of the opinio juris sive necessitatis".

It should be pointed out that customs defined by courtesy are excluded in this context. On the contrary, a practice may include abstentions. This is the case of prohibitive norms. The Permanent Court of International Justice confirmed this in the Lotus Case (PCIJ, 1927). One of the problems with the opinio juris is that of proving its existence in a practice, as it has to do with a psychological belief, i.e. it is abstract. One option is to refer to the material element of the practice. In this light, one can consider that the resolutions on international organizations in general and the United Nations' General Assembly in particular, are important in identifying the opinio juris. Furthermore, the doctrine affirms that the material and psychological elements are strongly related and cumulative (Haggenmacher, 1986): "A custom is the expression of a manifested opinio juris put in practice. It is not obtained by adding the two elements, but by the revelation of one by the other". Haggenmacher (1986) built a so-called two-element theory around this issue of evidence. According to this theory, the conviction of being legally bound can only be revealed by practice. There is therefore no possible differentiation between the material and psychological elements. In any case, the two-element theory lends some support to the approach of international courts in their various decisions. Finally, to ascertain proof of a custom, the international court considers the intention in the act of a State. Thus, in the North Sea Continental Shelf Case (ICJ, 1969), the International Court of Justice stated that: "The acts in question must show by their nature or the way in which they are accomplished proof that this practice is obligatory".

\section{Design of sustainable forests management States practice in Central America and the European Union}

In a bid to find the customary nature of SFM practice by the States, this review mainly applied the "inductive method" or "a posteriori approach" (Schwarzenberger, 1965), whereby rules on the sources of international law, especially customary ones, ought to be found in the practice of States and not in abstraction approach or "a priori" reasoning. The same method was also validated on several occasions by International Court of Justice (ICJ, 1969). But the inductive approach will be combined by the comparative laws method for better highlighting on some of the common and dissimilarities principles between both regional instruments (De Cruz, 1995).

\subsection{The case of Central America}

Primary forests in Central America cover $70 \%$ of the forest area of the region and $56 \%$ of the global natural forest coverage. Over 1000 tree species and over 6000 plant species have been identified in the Amazon forest (Mather, 1990). The natural forest area is estimated at 788008000 hectares (ITTO, 2006). However, because of the gradual conversion of forestlands mainly for agricultural purposes, the forest coverage reduction process is continuously slowing down (FAO, 2007). The majority of observers agree that the Amazon forest basin is the main source of fresh air in the world. This is the reason why it is considered crucial to typical international law issues, the international civil society (NGOs) and economic operators.

The main political and legal trends on SFM dynamics in the Central American region may first of all be drawn from a corpus on the Convention relating to the management and conservation of natural forest ecosystems, and for the development of forest plantations of 1993, signed by the Council for Central American Forests (CCAD). This is followed by the Convention on the conservation of biological diversity and the protection of priority forest areas of 1992, signed by the Council for Central American protected areas (CCAP). However, it must be noted that these regional legal instruments are part of a series of inter-State actions based on the Amazonian Cooperation Treaty (ACT). This regional institution with head quarters in Brazil is divided into four committees: economic, social, educational and environmental. The environmental committee is the operational organ through which sustainable management is promoted in the region (Elias, 2004).

Concerning the Convention on forest management and conservation of 1993, one notices first of all that the objectives set by the States concerned, according to Article 2 of the Convention include:

The promotion of national and regional mechanisms that could lead to change in land tenure practices on forest cover and potential;

The rehabilitation of degraded forest areas;

The reorientation of policies on forestland regulations;

The raising of awareness by discouraging actions that destroy forest cover;

The promotion of a planning process in the use of soils reserved for sustainable options.

Mention must be made of the fact that article 1 of the Convention, lays down the fundamental principles that govern the regional management of forest resources in these terms:

"According to the United Nations Charter and the principles of international law; the signing States of this Convention, reaffirm their sovereign right to proceed to use, manage and develop their forests in agreement with 
their own policies and regulations, as a function of: a) Their need for development; b) Conserving and sustainably using their forestry potential as a social and economic function; c) Ensuring that the activities under each control and jurisdiction, do not cause environmental damages to the country nor to other countries in the region; d) Strengthening the application of policies and strategies contained in the Forestry Actions Plans of each of the Member Countries".

In order to achieve the objectives spelt out in this regional agreement, member countries committed to implementing a number of actions that may be ranked among SFM initiatives. These undertakings may be seen in the wordings of the provisions of the various subsections of article 3. Actions towards the promotion of SFM are complemented, respectively, in provisions of articles 4(e) \& (f) and 6. Concerning the participation local communities and indigenous peoples in sustainable management process, the Convention stipulates in its Article 5. These regional initiatives aimed at sustainable management of forest resources in Central America, based on the two conventions previously mentioned above have already produced concrete results. The following results have been attained through sub-regional legal arrangements (Aguilar and Gonzales, 1999): the constitution of the Mesoamericain Biological Corridor, the creation and reinforcement of protected areas in cross-border regions such as Rio San Juan, the Honduras Gulf and Fonseca, etc., development of regional C\&I for SFM, harmonization of forest management laws and policies, adoption of certification systems tailored to regional realities.

\subsection{The case of the European Union}

The European Union is not a regional organization whose primary role is to manage the forests and other natural resources of its Member States. However, as a multilateral regional organization, it defines and influences the general policies of Member States in the economic, social, foreign policy, security and environmental sectors. The political subsystem and the community law applicable to forest resources fall therefore within the framework of the larger environmental component of the aforementioned organization. With regard to forest management, it should be noted that the European Union, in its capacity as a regional, interstate organization, applies the principle of subsidiarity (De Sadeler and Born, 2004). With regard to forestry potential, it covers $37.8 \%$ of European territory, and the Member States of the European Union rank second in the production of industrial logs and first in corkwood in the world (FAO, 2007).

It is important to mention that an evaluative study of forestry laws in 25 European countries revealed that reforms had been made since the 1990s aimed at amending the laws with relation to the social domestic demand of each country, and to the requirements of international instruments (Schmithüsen, 2000; Cirelli and Schmithüsen, 2003). As a result, this author concluded that the evolution of the structure of policies and laws in European countries henceforth reveal that sustainable forestry is no longer being relegated to the background. In other words, the author of these works confirms the existence of a sustainable forestry practice among these countries, on the one hand. On the other hand, he partially attributes this to the influence of soft and hard law international instruments. The European Union, during its various stages of development and name change, repeatedly intervened in forest management sector of its Member States. This was done through the laying down of many guidelines and other instruments (Schmithüsen, 2000). Its legal instruments bear on different elements relating to the management of the forest heritage in the Member States of the European Union. These include target-specific regulations aimed to respond to the different vectors harmful to forest clusters of the Member States. In the area of encouraging sustainability, directives No. 79/409/CEE of 2 April 1979 on the conservation of Wild Birds and No. 92/43/of 21 May 1992 on the Conservation of Natural Habitats and of Wild Fauna and Flora and the contribution of member countries to the different cycles of the Ministerial Conference on the Protection of Forests in Europe perfectly illustrate the common will in this regard. However, the additional legal elements on the conservation and sustainability of forests can be extracted from 'The Council Resolution of 15 December 1998 on a Forestry Strategy for the European Union'. But this EU regulation should be linked for better understanding with the 'Forest Action Plan 2007- 2011' issued in 2005, which gives some strategic details, especially on Forest Law Enforcement, Governance and Trade program (EFI, 2008).

First of all, in the Resolution relating to a forestry strategy, the Council, in what may be described as preamble of the text, defines the pace of its pro forest action in the corpus of the Resolution, in these terms:

"Having regard to the existing legislation of the Council concerning the forests sector, as well as the proposals on the support of forestry measures in the Member States made within the Framework of the Agenda 2 000; Considering the activities and commitments made by the European Union and its Member States in all relevant international processes related to forests, in particular the UN Conference for Environment and Development in 1992 in Rio de Janeiro and its follow- up, as well as the Ministerial Conference on the Protection of Forests in Europe and its Principles and Recommendations for the forest sector".

Next, the Council points out the importance of forests and determines the basic principles of its strategy on the aforementioned natural resources, in the following manner in parts 1 and 2 (a). Part 2 of the Resolution states in an explicit and clear way, from paragraphs $\mathrm{b}$ to $\mathrm{m}$, the specific operating principles on which its strategy is based. In detail, these principles include: the principle of subsidiarity; the fact that the measures adopted or envisaged contribute to the implementation of a forestry strategy and the support of the States in sustainable management; 
participation in all international processes related to forests; the important role of a sustainable management of forests in increasing biological diversity and its contribution to the fight against climate change; the promotion of the use of timber and of other products from sustainably managed forests; the contribution of forestry and of industries of the timber sector to income; the necessity for an integration of forests and of forest products in all common sectoral policies, etc. This Resolution Programme is pursued through the enumeration of "community actions related to forests and forestry" that the organization is considering for Member States.

\section{Towards the customary law nature of SFM in both regions}

\subsection{The Customary nature of SFM States practice}

As a reminder, to describe a practice or State behavior as international custom, two basic conditions must be met: a material condition (consuetudo) and a psychological condition (opinio juris). In the same way, do the sustainable forest practices of the two regions mentioned above meet the basic conditions of international custom? The following analysis will shed some light on this question.

\subsubsection{Material elements for the States practice on SFM}

Admittedly, international custom springs from a usage founded on positive or negative actions. In the case of Central America, the usage on which custom is based is felt through interstate acts that call for the sustainable management of the zone's forest ecosystems. Similarly, one would observe that the aforementioned interstate practices relating to sustainable forestry can all be classified under the hard Law category. In effect, Central America's regional legal instruments, one of which relates to the conservation of biodiversity (1992) and the other to the conservation and sustainable management of forests (1993), are outright regional conventions. Consequently, these fall within the framework of binding interstate legal acts. With regard to the two texts enacted by the European Union, they fall within the category of acts issued by a regional multilateral organization, for its member States. It can be noted that the two instruments- the Resolution of 15 December 1998 and the Action Plan of 15 June 2006- are part of the soft law, thus devoid of any binding character. The latter are a part interstate acts that influence policies, regulations and actions within Member States.

The theory and the jurisprudence of international law require that practice be repetitive and consistent with time (Henckaerst, 2005). This condition is verifiable at two levels: the consistency and the duration of the practice at issue. In the case of Central America, the practice of sustainable management began in 1993, following the adoption of the convention on the conservation and sustainable management of forests. The behavior of sustainable forestry has therefore been temporally repetitive since 1993 . With regard to the second aspect, which is consistency in practice, it is unique in the sense that all the signatory Member States adhere to the treaty provisions. Furthermore, the forests of this geographical area are relatively homogenous because they are to a large extent part of the Amazonian basin. Sustainable forestry is therefore consistent with the objective of sustaining forest resources in the long term, and the content of the instruments in terms of tropical forest management is fairly similar as well.

In the case of the European Union, the practice of SFM is equally repetitive and consistent with time. In effect, as if to lay more emphasis, Schmithüsen's works (2000), demonstrate that European States amended their policies and forestry regulations as required by shifts in international trends on sustainable forestry. So the 1998 Council Resolution and the 2006 Action Plan relating to forests constituted a reiteration and crystallization of the practice of sustainable forestry, already effective in each Member State. There is therefore repetition in time because the first forestry reforms in some Member States of this regional organization go back to 1994, as in the case Sweden. Additionally, there is consistency in the objective and content, which is the long term management of the forest resources of temperate ecosystems. Furthermore, this agrees with international jurisprudence in the Asylum Case (ICJ, 1950), in which the judge esteems that consistency must be substantial.

Secondly, theory and jurisprudence require that States practice be consistent with space (Brownlie, 2003). In the case of Central America, the requirement relating to consistency in practice is met by the fact that the Member States to the two conventions are typical of the Amazonian forest basin. This tropical forest basin is, in effect, the primary lung that supplies oxygen to the entire planet and its potential in biodiversity is indisputable (Mather, 1990). Regarding the case of the European Union, sustainable forestry practices are equally consistent with space. In effect, according to the FAO (2007), the Member States of this regional grouping are the world's second largest producers of industrial roundwood and the first largest producers of cork. They are therefore typical of those countries that are particularly concerned with forestry management at a global level.

\subsubsection{Psychological element for the practice of SFM in the two regions: opinio juris}

The psychological condition, also known as « opinio juris», practiced by States or international organizations involves recognizing the binding character of the material act. In other words, State practices are influenced by common conviction that the adoption of attitudes in keeping with the agreed act is legally binding: This is « opinio juris ». In the case of sustainable management practices of forests in Central America, the objective of the States, signatories to the two conventions, to create binding legal obligations is clear and explicit. In effect, countries that are members to these two legal agreements relating to the conservation of biodiversity and to forests have deliberately and consciously described their acts as conventions. Consequently, opinio juris is directly connected 
to the two material acts at the time they were signed by the States. Opinio juris is necessarily incidental to consuetudo (Daillier and Pellet, 2002).

In the case of the European Union, the two acts of this organization have the nature of soft law. There is thus no obligation that is directly binding on its Member States. Nevertheless, as required by the doctrine of international law, in acts that come under soft law, such as the Council's Resolution, opinio juris should sought at the time of its adoption, where the parties were unanimous (Henckaerst, 2005). The unanimous adoption of a resolution within an international organization reveals in effect the intention of the members to be legally bound in the medium or long term by the content of the act. This is the case with countries of the European Union. No Member State has protested against either the December 1998 Resolution and the 2006 EU Action Plan relating to forests, until now. Consequently, the countries of this regional institution were visibly unanimous in their intention to be legally bound by the content of the instruments relating to forests.

Finally, the aim to generate legally binding obligations on sustainable forestry, among the two regional blocs can also be extracted, through a unanimous vote by the members of the General Assembly of the United Nations, from the following two resolutions: No 47/191 of 1992 and No 48/190 of 1993. In effect, the two resolutions underline the now fundamental character of principles adopted at Rio, where all world governments were called upon to promote and translate them into concrete acts. In fact, the absence of opposition from any State belonging to the two blocs in question or from any country whatsoever is a demonstration of the adherence to the concept of sustainable development and to the derived notion of sustainable forestry.

\subsection{Some similarities between the two regional regimes}

The objective of this subsection is to reveal some shared principles between both geographic areas. On the basis of the sustainable forest management concept that figures in the two regional instruments, one can identify some major principles guiding current international environmental law. It should first be noted that environmental law is based on some major legal principles of a conventional, customary or simply of a declaratory nature (Prieur, 2001). It is difficult to classify the said principles of international environmental law that is generally accepted by observers (Lang, 1999; Paradell- Trius, 2000). Nevertheless, it is possible to underline a part of the principles that result directly or indirectly from our interpretation of the three regional forest sustainability regimes.

The first principle relates to recognizing the right of future generations (Prieur, 2001). Forest sustainability involves existing generations. However, overexploitation and degradation of forest resources can lead to irreversible damage that will affect future generations: intergenerational and intragenerational equity. Therefore, the three regional instruments have apparently taken this need into consideration, by legally integrating the concept of sustainable forest management into their instruments. Actually, this involves taking in principle 3 of the Rio Declaration on the environment and future generations. This mainly involves the institutionalization of techniques such as sustainable forest management, forestry, regeneration and reforestation, likely to preserve these forest resources in the long term for future generations.

The second is the principle of prevention. This entails taking appropriate measures to prevent any serious damages to the environment. Prevention is action that is both anticipatory and preliminary. In the forest sector, the duty of prevention is a requirement that is likely to reduce the rate of unrelenting extinction of forest resources. Practically, tools like the Environmental Impact Assessment (EIA); low-impact Industrial logging (in tropical areas); rotation in accordance with management plans, which are instrumental both in preventing and safeguarding forest blocks from being damaged, are henceforth institutionalized and effective in the logging sector in the two geographical zones.

The third principle is that of precaution. In the face of the irreversibility of some environmental damages and of scientific uncertainty, and in a bid to protect ecosystems, another form of prevention was developed. This basically involves practical codes of conduct earmarked for States as well as other stakeholders that exploit forest resources. This third principle is implicit in the three regional forest sustainability regimes. It is clearly stated in principle 15 in the Rio Declaration.

The fourth principle is participation. This involves the right of citizens to participate in forest management activities. The preservation of forest resources is the duty of States and various social mechanisms. The universal nature of ecosystems, their interdependence as well as the irreversibility of environmental problems relating to their natural resources makes it necessary that citizens participate in forest management. Principle 10 of the Rio Declaration upholds the involvement of citizens in environmental management. In fact, the three regional forest sustainability regimes provide for the involvement of citizens in forest management in different ways. Thus, these regimes uphold common tools such as the delegation of management responsibilities and the decentralization of forest resources to peripheral entities of central States (Larson, 2005). In other words, it entails setting up collaborative frameworks to enhance citizens participating in forest management in the three geographical regions. The fifth is the principle of international cooperation. International cooperation in favour of long term preservation of forest resources is a necessity imposed by the global nature of the ecosystem. In the Rio Declaration, the obligation to cooperate is mentioned in principle 7. At the level of regional forest management instruments, international cooperation was explicitly mentioned in legal provisions. In addition, transboundary management 
dynamics are already part of the requirements of regional interstate cooperation, which is complementary to the actions of both individual States and the international community. It embraces several areas, namely, collaborative work plans, funding of projects, technical aid, and transfer of technology through grants, training of experts.

The sixth principle is permanent sovereignty over forest resources. Each State has the sovereign right to exploit and enjoy forest resources within its territory, admittedly with the proviso that exploitation activities do not cause damage in neighbouring jurisdictions; that the duty of international cooperation is taken into consideration and good faith shown in interstate relations. Based on the United Nations General Assembly, December 14, 1962 Resolution, this principle is constantly inserted in various multilateral agreements relating to the management of environmental resources (Kuokkanen, 2006). With this fact in mind, regional forest sustainability regimes are no exception. While this principle is implied in the European Union, countries in Central America have underlined it in a clear-cut manner in their instruments.

The seventh is the principle of subsidiarity: This principle enables each Member State of a regional or international group to use its power or discretion to adapt the principles laid down in a global instrument to the national context. In this way, the principle of subsidiarity appears to be an extension of the principles of cooperation and the sovereignty of States. Within the framework of regional forest sustainability instruments, subsidiarity permeates the three geographical regions. As a matter of fact, all Member States belonging to each regional group have their own forestry legislation. Such legislation must simply be consistent with the spirit of and commitments made in both regional instruments and international processes.

\subsection{Differences between the two regional forest sustainability regimes}

The first main type of contextual specificity that is the focus in this comparative study of regional SFM regimes in the two regions is the nature of existing forests. In fact, Central American forest ecosystems around the Amazon Basin belong to tropical forests (FAO, 2007). On the other hand, the forests in the European Union Member States are classified as temperate forests in the south and centre of the continent and boreal forests in the north of the continent (FAO, 2007). This distinction of forest types is of double importance. First, it is known that tropical forests are home to more than half of the biodiversity of the world's forests (Burley, 2002). Thus, Mather noted that in the Amazon there are almost 6000 plant species that are mostly endemic to the region across over 2 ha with over 300 different species (Mather, 1990).

Considering this difference of forest biodiversity, SFM policies cannot be similar to those of the European Union. In this vein, it has been demonstrated that each forest ecosystem management regime should be based on the ecological, social and political realities of the area (Colfer, 2005; Diaw, 2009). Consequently, the principle of ecological sustainability as stated in the Rio document could not be applied in a uniform, homogenous or similar manner across the ecosystems in tropical forests, as in geographical areas made up mostly of temperate or boreal forests. Therefore, the ecological function of forest sustainability from which the principle of the same name is obtained, depends on the nature of the existing ecosystems. This need to adapt to the natural milieu has some consequences on the instruments, tools and the techniques for sustainable forest management such as sylviculture and forest management plans and Criteria and Indicators.

The second difference between Central America and European Union SFM regimes is related modalities of social sustainability. Indeed, the principle of social sustainability described in these regional instruments has two forms, namely, participatory management and forest ownership. With regards to participatory management, provisions of Central America Convention are explicitly and clearly call for the involvement of the various social components in the forest management process. On the contrary, the public participation in forest management in the European Union is implicit. The principle is referred to through words like 'use' and 'the quality of life'. It is thus necessary to look at domestic laws in Member States to explicitly identify the social function of forest resources.

Furthermore, another particularity of each regime can be identified from the review of some provisions. This concerns access to forest resources and ownership. According to FAO (2005), ownership and access rights to resources have an impact on the progress of sustainable forest management. Hence, it should be noted that European Union States clearly mention that: "the need to promote a transparent approach that includes the participation of all interested parties considering the diversity of ownership regimes within the community, which makes the participation of forest owners necessary". On the contrary, the Central America instrument does not make any mention of access to forest resources.

The third major difference is related the principle of economic sustainability. Indeed, the advanced level of development of European Union Members influences the situation of forest economy in the region. Thus, forest economy is characterized by a strong processing industry and the mastery of modern technologies. In fact, the FAO (2007), announces the reduction of the contribution of the sector to the Gross Domestic Product indicator (GPD) from 1.5 to 1.2 percent between 1990- 1992. In the case of the Amazon Basin, the forest economy is marked by the beginning of the industrialization of raw materials in processed products. However, there is still a significant margin of exports of raw materials and the contribution of the forest economy to the GPD indicator is the highest in the world. 


\subsection{Logical implications of the States practice on SFM}

The foregoing analysis proves that SFM practices in Latin America and within the European Union meet all the theoretical and precedential requirements necessary to attain the status of international custom. In effect, it is necessary to state some of the implications of these findings.

Taking in account to effective States practice in the two regional blocs, the first legal implication resulting from analyzing the practice of SFM in Central America and the European Union is that the principles of sustainable forestry laid down at Rio have already attained the status of regional custom in each geographical zone. Consequently, the sustainable management of forest resources is legally binding on all the States and other actors operating in the two geographical zones. In effect, the 1993 Convention on the conservation and the sustainable management of forests and forestry planting of Central America, led to the emergence of a practice of States, and this then generated the custom of sustainable forestry. In other words, one can say that the two Central American conventions directly gave rise to the region's customary standard. On the contrary, in the case of the European Union, the 1998 Resolution and the Action Plan relating to forests had telling effects. To this effect, they lay down or place on record an effective sustainable forestry practice among Member States. Furthermore, it should be emphasized that in the case of Central America, the concept of sustainable management of forests acquired a significant legal content by means of its inclusion in a binding legal instrument. This constitutes some significant progress because the convention was born one year after Rio, while the global concept of sustainable development had not yet acquired a significant and procedural legal character (Sands, 1999).

The second legal implication is that the theory and the jurisprudence of international law are confirmed upon a closer examination of the evaluation. In effect, the essential requirements, which form the backbone of international law, are totally met in the case of a transition from State practice of sustainable forestry to the standard phase. But a comparison of the practices of both Central America and Europe, nevertheless, reveals that the theoretical and jurisprudential requirement relating to standardized practice is not fully met in this particular case. In effect, the two instruments on sustainable forestry are the same at the level of their objective: to conserve or manage forest resources in the long term. However, there are some slight differences at the level of the content or substance of the instruments, owing to the fact that the forest ecosystems involved are basically different: tropical forests in Central America and temperate forests for the European Union. Considering that any sustainable forest management depends on the forest biodiversity potential and on the social factors, one is forced to assume that instruments on sustainable management between Central America and countries of the European Union contain some peculiar differences arising from the natural environment. To this end, Mather (1990) notes that more than 300 plant species can be found on every 2 ha of an Amazonian forest cluster, whereas, according to FAO (2007), about 4 - 8 species can be found on the same surface area in temperate forests. These findings on the existence of differences in the uniformity of State practice regarding sustainable forestry confirm the observation made by Bodansky (1995), on the relativity of consistency in State practice: "Finally, customary rules represent regularities, but not necessarily uniformities of behavior", the one hand. On the other hand, such findings contribute to what legal doctrine considers the singularity of international environmental law within the greater frame of international law (Bodansky et al., 2007).

The third implication that can be inferred from this analysis is the Erga omnes character of the obligations arising from the emergence of an international customary standard on sustainable forestry. Admittedly, forest ecosystems are clearly set within the borders of nation-States, and must subsequently constitute a sovereign right-of-way as regards exploitation (UNGA, 1962). Nevertheless it has been known for years that flora and forest fauna are part of the common heritage of mankind (Kiss, 1982). In the same way, deforestation is now part of the "Common concerns" at a global level (Brunnée, 2007). Consequently, the obligation to sustainably manage and conserve forest resources is henceforth Erga omnes (obligation that is owed to or in relation to all the entire intentional community) with regard to the international community and brings with it all the effects related to the responsibility of States in case this type of obligation is not respected (Birnie and Boyle, 2002).

Finally, the unanimous adoption of Resolutions No 47/191 of 1992 and 48/190 of 1993, relating to the Declaration and the principles laid down at Rio, by all the member States of the General Assembly of the United Nations, signifies that all subjects of international law should expect it will inevitably give rise to international custom, through the lens of State practice. It is the case of the 1992 forest principles, unwavering in the beginning, which are giving rise to the international customary standard on sustainable forestry, thanks to the practice of States and other actors. Therefore, any contrary position by a State should be interpreted as bad faith in international relations. In effect, in the Chorzow Factory Case, the Permanent Court of International Justice (PCIJ, 1927), stated the following dictum: "no one can override his own turpitude". In other words, the States that adopted the two resolutions on sustainable development cannot avail themselves of the fact that they did not know that these two instruments could give rise to States practice and subsequently to customary law.

\section{Conclusion}

An examination of the relationship between SFM and customary international law reveals that consistent and effective States practice especially that of Central America and the European Union is progressively built and emerged a customary standard on sustainable forest management that was initially regional level. In effect, it 
would be reasonable even logic to consider the sustainable management of forest resources at regional levels (Central America and European Union) as legally binding, not at a conventional manner, but at a customary one. In reality, the 1992 forest principles laid down in Rio that are not legally- binding sufficiently encouraged States practice, and such, besides, was their initial objective. This analysis largely validates the theory and the jurisprudence of general international law relating to the conditions necessary for the creation of international custom, consuetudo and opinio juris, on the one hand. On the other hand, however, it has made it possible to ascertain once again the peculiarity of international environmental law within the wider frame of general international law. From this last perspective, the analysis underlined the fact that the theory of consistency in States practice should be put in perspective with regard particularly to sustainable forest management. This is because it is obvious that in the area of sustainable forest management, States acts may be consistent and uniform with reference to objectives and formal levels.

On the contrary, natural/ecological and social factors require that the peculiarities specific to each forest ecosystem be taken into account in the implementation of sustainable management suitable for a variety of contexts; not an approach that would involve searching for or even imposing at all costs a homogeneous sustainable management practice on all types of forest. To this effect, some works have further revealed that any effective management of forest clusters should be based on the ecological, social and political realities of the environment of its implementation (Colfer, 2005; Diaw, 2009).

Therefore, whatever the case may be, taken hostage by the egocentric reasoning peculiar to the sovereignty of States at a conventional instrument, the building of international law regime on sustainable forest management is poised to succeed via the "casual process" of making international law. Such logical conclusion is, on one hand confirmed the theory of the sources of the international law that recognized international custom as such (Kelsen, 1945); on the other hand, the results show that the international norms of SFM are currently emerging of the States practice. The analysis should contribute to a better understanding of the building process of international norms related forests management from the regional to the global level. In the perspective of this paper, the customary law regarding the sustainable forest management and conservation can be seen in the large canvas of an emerging international regime, whereas in the past, the conservation of forests resources has been in the sole jurisdiction of each State. This domestic focus has been weakened and is, to extent, being supplanted by the universal concerned of the need to promote sustainability and to preserve forest biodiversity in the time of climate change and global warming. Nevertheless, it would be necessary to nuance such conclusion on customary international law theory, because like Bodansky (1995) said: "The doctrine of opinio juris serves to introduce the internal point of view into the concept of customary law: customary norms depend not only on States practice (that is, on observable regularities of behavior), but also on acceptance of these regularities as law by States".

\section{References}

Aguilar, G \& Gonzales, M. (1999). Regional Legal Arrangements for Forests: The Case of the Central America. In Tarasofsky, R. G. (ed.), Assessing the International Forest Regime (pp. 113- 120). IUCN: Gland.

Akehurst, M. (1975). Custom as a Source of International Law. B.Y.B.I.L 1974- 1975, 1- 53.

Birnie, P \& Boyle, A. (2002). International Law and the Environment. Oxford: Oxford University Press.

Birnie, P and Boyle, A. (2002). International Law and the Environment. Oxford: Oxford University Press.

Boczeck, B.A. (2005). International Law. A Dictionary: Dictionaries of International Law. London: The Scarecrow Press.

Bodansky, D., Brunnée, J and Hey, E. (2007). International Environmental Law: Mapping the Field. In Bodansky, D., Brunnée, J \& Hey, E (eds.), International Environmental Law: The Oxford Handbook (pp. 1- 27). Oxford: Oxford University Press.

Bodansky, D. (1995). Customary (and not so Customary) International Environmental Law. 105 Global Legal Studies Journal, Vol. 3: 105- 109.

Boisson de Chazournes, L. (2004). Qu'est - ce que la Pratique en Droit International? In La Pratique et le Droit International (pp. 13- 47). Paris: A. Pedone.

Brownlie, I. (2003). Principles of Public International Law. Oxford: Oxford University Press.

Bruenig, E.F. (1996). Conservation and Management of Tropical Rainforests: An Integrated Approach to Sustainability. London: CAB International.

Brundlandt Report. (1987). Our Common Future. Oxford: Oxford University Press.

Brunnée, J. (2007). Common Areas, Common Heritage and Common Concern. In Bodansky, D., Brunnée, J and Ellen Hey (eds.), International Environmental Law: The Oxford Handbook (pp. 550- 573). Oxford: Oxford University Press.

Brunnée, J. (1996). A Conceptual Framework for an International Forest Convention: Customary Law and Emerging Principles. In Global Forest and International Environmental Law (pp. 41- 77). Montreal: Kluwer International Law/Canadian Council on International Law.

Burley, J. (2002). Forest biological diversity: an overview. Unasylva, No 209, Vol. 53: 6- 13. 
CARPE. (2005). Congo Basin Forests: Preliminary Assessment. Report online http//carpe.umd.edu/product. Accessed on April 5, 2006.

CBFP. (2006). Situation des Forêts du Bassin du Congo 2006. Kinshasa : CBFP.

Cirelli, M.T and Schmithüsen, F. (2003). Europe Occidentale. In Cirelli, M.T., Schmithüsen, F., Texier, J \& Young, T (eds.), Tendances du droit forestier en Afrique et en Europe. Rome: FAO.

Colfer, C.J.P. (2005). The Complex Forest: Communities, Uncertainty and Adaptive Collaborative Management. New York: RFF/CIFOR.

Condorelli, L. (1991). La coutume. In Mohammed Bedjaoui (ed.), Droit International: Bilan et Perspectives (pp. 187- 221). Paris: UNESCO/A. Pedone.

Cordonier Segger, M.C. (2008). Sustainable Development in International Law. In Bugge, H.C\& Voigt, C (eds.), Sustainable Development in International Law and National Law: What did the Brundland Report Do to the Legal Thinking and Legal Development, and Where Can We Go from Here (pp. 87- 179). Groningen: Avoseta/Europa Law Publishing.

Daillier, P and Pellet, A. (2002). Droit International Public. Paris: LGDJ.

De Cruz, P. (1995). Comparative Law in a Changing World. London: British Library Cataloguing in Publication Data.

De Sadeleer, N and Born, C.H. (2004). Droit International et Communautaire de la Biodiversité. Paris: Dalloz.

Diaw, M.C. (2009). Introduction: Theory and Practice of Adaptive Collaborative Management. In Diaw, M.C, Aseh, T \& Prabhu, R (eds.), In Search of Common Ground: Adaptive Collaborative Management in Cameroon (pp. 1- 40). Bogor: CIFOR.

Dryzek, J.S. (2007). Paradigms and Discourses. In Bodansky, D, Brunnée, J \& Hey, E (eds.), International Environmental Law: The Oxford Handbook (pp. 44- 62). Oxford: Oxford University Press.

EFI. (2008). Forest Law Enforcement, Governance and Trade. Joensuu: EFI.

Elias, E. (2004). The Parapoto process: establishing criteria and indicators for the sustainable management of Amazon forests. Unasylva, No 218, Vol.55: 47- 52.

FAO. (2007). State of the World's Forest 2007: Executive Summary. Rome: FAO.

FAO. (2005). State of the World's Forest 2005: Executive Summary. Rome: FAO.

FAO. (1999). State of the World's Forest 1999. Rome: FAO.

Ferrari- Bravo, L. (1986). Méthodes de Recherche de la Coutume Internationale dans la Pratique des Etats. In Recueil des Cours, Académie de Droit international 1985. Tome 192. La Haye: Martinus Nijhoff.

Haggenmacher, P. (1986). La doctrine de deux éléments du droit coutumier dans la pratique de la Cour Internationale de Justice. 90 RGDIP : 1 - 114.

Hashiramoto, O., Castano, J and Johnson, S. (2004). Changing Global picture of trade in wood Products. Unasylva No 219, Vol. 55:19- 24.

Henckaerts. J.M. (2005). Study on Customary International Humanitarian Law: A Contribution to Understanding and Respect for the Rule of Law in Armed Conflict. International Review of Red Cross, No 857, Vol. 87: $175-212$. Humphreys, P and Palo, M. (1998). Forests in Global Warming. Helsinki: UNU/WIDER.

ICJ. (1997).The Gabcikovo- Nagymaros Project Case (Hungary v Slovakia), Rep. 1997, at http://www.icj-cij.org. ICJ. (1996). Advisory Opinion on Legality of the Threat or Use of Nuclear Weapons, Rep. 1996, at http//www.icj-cij.org

ICJ. (1986). The Nicaragua Case. Rep. 1986, at http//www.icj-cij.org

ICJ. (1969). The North Sea Continental Shelf Case. Rep. 1969, at http://www.icj-cij.org

ICJ. (1950). The Asylum Case. Rep.1950, at http://www.icj-cij.org

IPCC. (2007). Climate Change 2007. The Physical Sciences Basis: Summary for the Policymaker. Report online http://www.ipcc.ch.Accessed on August 5, 2007.

IL A. (2000). Final Report of the Committee: Statement of Principles Applicable to the Formation of General Customary Law 2000. London Proceedings: ILA.

ITTO.(2006). Status of Tropical Forest Management 2005: Summary Report. Yokohama: ITTO.

Kelsen, H. (1945). General Theory of Law and State. Cambridge: Mass.

Kennedy, D. (1987). The Sources of International Law, 2 Am.U.J. Int'l L. \& Policy No 1.

Kiss, A. (1982). La Notion de Patrimoine Commun de l'Humanité. In Recueil des Cours Académie de Droit International, Tome 175 (pp. 103- 244). La Haye : Martinus Nijhoff.

Kuokkanen, T. (2006). Background and evolution of the Principle of Permanent Sovereignty over Natural Resources. In Berglund, M (ed.), International Environmental Law-making and Diplomacy Review 2005 (pp. $97-$ 108).Joensuu: University of Joensuu/UNEP. 
Kuokkanen, T. (2002). International Law and the Environment: Variations on a Theme. The Hague: Kluwer Law International.

Lang, W. (1999). UN- Principles and International Environmental Law, Max Planck UNYB3: 157- 172.

Larson, A. (2005). Democratic Decentralization in the Forestry Sector: Lesson Learned from Africa, Asia and Latin America. In Colfer, J.P.C \& Capistrano, D (eds.), The Politics of Decentralization: Forests, People and Power (pp. 32- 62). London: Earthscan.

Maini, J.S. (1992). Sustainable development of forests. Unasylva, No 43: 5- 13.

Mather, A.S. (1990). Global Forest Resources. London: British Library Cataloguing in Publication Data.

MCPFE. (1993). European List of Criteria and Most Suitable Quantitative Indicators 1993, At http://www.minconf-forest.net.

Ndoye, O and Tiguhong, C. J. (2004). Forest Resources and Rural Livelihoods: The Conflict between Timber and Non- Timber Forest Products in Congo. Scandinavian Journal of Forest Research, 19 (4): 36- 44.

Paradell- Trius, L. (2000). Principles of International Environmental Law: An Overview. RECIEL, 9 (2): 93- 99.

PCA. (2005). The Arbitration regarding the Iron Rhine Railway (The Kingdom of Netherlands v Kingdom of Belgium), at http:// www.pca.org.

PCIJ. (1927). The Chorzow Factory Case. Rep. 1927. Serie A, at http://www.icj-cij.org

PCIJ. (1927). The Danube Case. Rep. 1927. Serie A, at http://www.icj-cij.org

PCIJ. (1927).The Lotus Case. Rep. 1927. Serie A, at http://www.icj-cij.org

Prieur, M. (2001. Droit de l'Environnement. Paris: Précis Dalloz.

Princen, T. (2003). Principles for Sustainability: From Cooperation and Efficiency to Sufficiency. Global Environmental Politics, 3: 33- 50.

Poore, D., Burgess, P., Palmer, J., Rietbergen, S and Synnob, T. (1989). No Timber without Trees: Sustainability in the Tropical Forest. London: Earsthscan Publication.

Ruis, B.M.G. (2001). No Forest convention but ten trees treaties. Unasylva, No 206, Vol. 3: 12- 17.

Sands, P. (1999). International Courts and the Application of the Concept of Sustainable Development. Max Planck UNYB3: 389- 406.

Sands, P. (1995). Principles of International Environmental Laws. Volume 1: Framework, Standards and Implementation. Manchester: Manchester University Press.

Schmithüsen, F. (2000). The Expanding Framework of Law and Public Policies Governing Sustainable Uses and Management in European Forests. In Schmithüsen, F., Herbst, P \& Le Master, D.C (eds.), Forging a New Framework for Sustainable Forestry Recent Development in European Forest Law. Vienna: IUFRO.

Schoene, D and Netto, M. (2005). The Kyoto Protocol: what does it mean for forest and forestry? Unasylva, No 222, Vol. 56: 3- 11.

Schrijver, N.J. (2008). The Evolution of Sustainable Development in International Law: Inception, Meaning and Status. The Hague: Martinus Nijhoff.

Schwarzenberger, G. (1965). The Inductive Approach to International Law, cited by ILA 2000.

Smouts, M.C. (2008). The Issue of an International Forest Regime. International Forestry Review, Vol.10 (3): 429- 432.

Stern, N. (2006). The Economics of Climate Change: The Stern Review 2006, Report Online http://www.hm-treasury.gov.uk/indenpendent review. Accessed on May 4, 2007.

Sverdrup, H and Mats Svensson, G.E. (2002). Defining Sustainability. In Sverdrup, H \& Stjlinquist, I (eds.), Developing Principles and Models for Sustainable Forestry in Sweden (pp.21- 32). Boston/London: Kluwer Academic Publisher.

Tarasofsky, R.G. (1999). Assessing the International Forest Regime: Gaps, Overlaps, Uncertainties and Opportunities. In Tarasofsky, R.G (ed.), Assessing the International Forest Regime (pp.3- 11). Gland: IUCN.

Thirlway, H. (2003). The Sources of International Law. In Malcom D. Evans (ed.), International Law (pp. 117144). Oxford: Oxford University.

UNGA. (1962). Permanent Sovereignty Over Natural Resources, Resolution No 1803 (XVII).

Vähänen, T. (2006). Forests and the Millennium Development Goals. In Berglund, B (ed.),

International Environmental Law- making and Diplomacy Review 2005 (213- 225). Joensuu: University of Joensuu/UNEP. 